IP Periodica Polytechnica Architecture

48(2), pp. 106-112, 2017

https://doi.org/10.3311/PPar.11621

Creative Commons Attribution (i)

RESEARCH ARTICLE

\section{Mass Heritage of New Belgrade: Housing Laboratory and So Much More}

\author{
Jelica Jovanović1*
}

Received 17 November 2017; accepted 06 December 2017

\begin{abstract}
The central zone of New Belgrade has been under tentative protection by the law of the Republic of Serbia; it is slowly gaining the long-awaited canonical status of cultural property. However, this good news has often been overshadowed by the desperation among the professionals, the fear among flat owners and the fury among politicians: the first because they grasp the scale of the job-to-be-done, the last because it interferes with their hopes and wishes, and the second because they are stuck between the first and the third group. This whirlpool of interests shows many properties of New Belgrade, that stretch far beyond the oversimplified narratives of 'the unbuilt capital of Yugoslavia', 'the largest dormitory of Belgrade' and 'the unrestrained modernist playground'.

This paper attempts to offer other points and value nods to those that are the most frequently used, from the complexity of the integrative efforts to the emergence of this new city, as well as the omitted and overlooked aspects of its reconstruction, deregulation and failure. The focus of the paper is the emergence, the use and the disappearance of the peculiar Yugoslav prefabricated housing, the path less travelled.
\end{abstract}

\section{Keywords}

New Belgrade, mass housing, laboratory, prefabrication
${ }^{1}$ Institute for Art History, Archaeology and Preservation, Faculty of Architecture, University of Technology Vienna, Karlsplatz 13, 1040 Wien, Austria

*Corresponding author, e-mail: jelica.jovanovic011@gmail.com

\section{Introduction}

It might be difficult for us today to grasp the joy and enthusiasm of the post-war generation of planners and builders, once New Belgrade had started to emerge from the swampy sand of the left bank of the Sava river. The symbolic burden of the vast marshland, which served as a no-mans-land between the Ottoman and Habsburg Empire, could not be automatically annulled after the formation of the first Yugoslavia in 1918. It took another twenty-something years, a world war and a revolution to get there. However, as well as the political and economic issues, there was a set of organisational and technological obstacles to creating this city.

The author would argue that without the integration of industrialisation and urban planning, New Belgrade would not have been possible to build, at least not in such a ratio of timeto-space coverage, as we know it today. Similarly, it is this, in many ways intangible heritage, that needs to be emphasised, further researched and understood when examining the physical structure of New Belgrade. This paper refers to mass housing as mass heritage for two main reasons: first, the scale and numbers of it, as something quite different from the heritage previously known; and second, due to its emergence on a vast scale in a short period, which required effective and integrated organisation of the production process, the aspects of which is described in the text.

\section{The Development of New Belgrade: Struggle, Makeshift, Integration}

By 1946, the left bank of the Sava was set to become the new capital of the new, second, socialist Yugoslavia. This was seen as proving to all the "doubters" that the Yugoslavs - after liberating and reclaiming their country - had the will, the energy and the knowledge to build their capital from scratch; the funding was a separate issue. Early on, Yugoslavia took a separate path from the Soviet Union model of socialism, which led the Eastern bloc to expel Yugoslavia with the Kominform resolution in 1948. This caused the deepening of the already severe economic crisis in the country ravaged by the war. Yugoslavia depended on international assistance, but the roots of the new 
economy were based both on Soviet knowledge and experiences - and on Soviet loans. Hence, many processes came to a halt simply because there was no funding whether it was the construction of the building for the Presidency of the Government of FNRJ (later the Federal Executive Council) or draining the swamp of the future site of the New Belgrade; the same rule applied - no funding available.

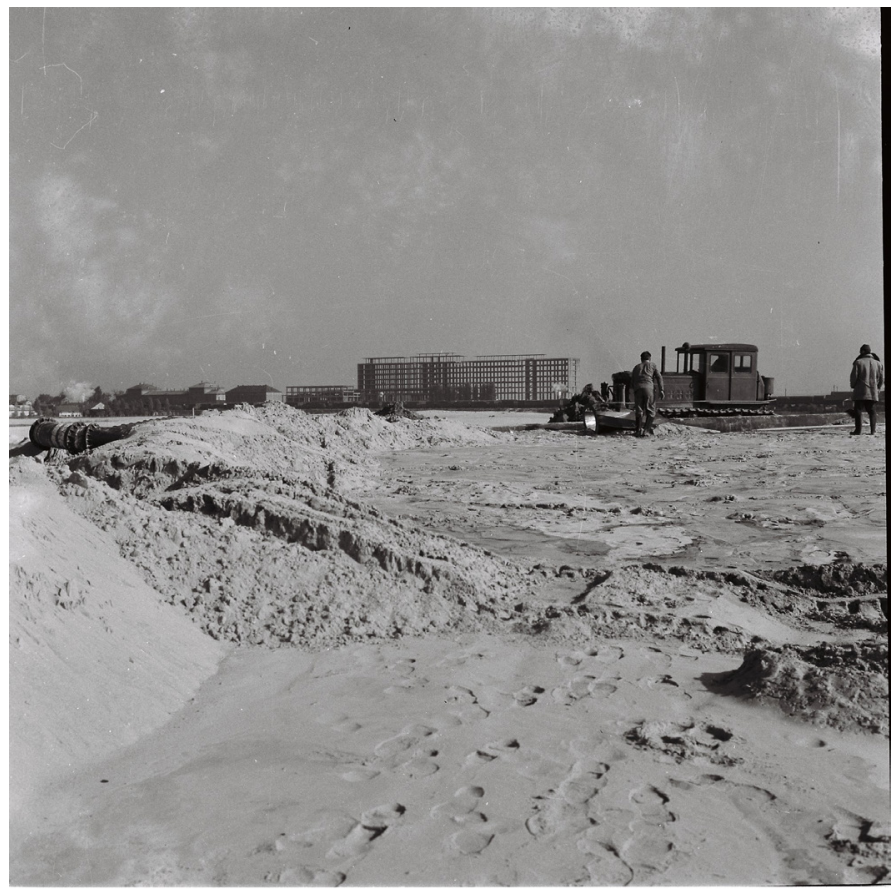

Fig. 1 Federal Executive Council's unfinished building, beginning of the 1960s. Source: Urban Planning Institute of Belgrade

Although obviously very expensive and labour intensive, the construction of the new capital would pay off in the long run. The land was not owned by anyone, except for small areas in the Army's possession - hence there was no need for expropriation. The area was a swamp, hence no need to create tabula rasa conditions in the Le Corbusian sense of the term, by tearing down the existing structures. Furthermore, the centuries-old biohazard of the unregulated swamp in the centre of Belgrade would be removed, and the city would get additional land for expansion - housing being the biggest priority in this case.

Informed by examples of countries that were already ahead in housing construction, Yugoslavia took its first steps towards building the capacities for an industrialised housing economy. This was a path taken energetically both by the East and the West, to resolve the worsening housing crisis, as the result of the war. The First Five Year Plan (1947-1951) of Yugoslavia, which had the power of a federal legal act, explicitly stated the industrialisation of housing construction as one of the country's priorities, alongside the specific names of the cities that would receive special attention. Belgrade (together with Ljubljana and Titograd) was one of them since it had to become the appropriate capital to the federation and house the most important administrative, cultural and educational facilities. Above all, the much-needed planning institutions, that would be able to absorb and deal with the amount of work ahead of them. These were all the necessary pre-conditions for the emergence of New Belgrade, but it took almost a decade for these actors to, first, consolidate, and then coordinate among themselves - for the city to start to emerge as a result of their integrated actions.

\section{The Path of Industrialization: "Crane" and "Gabarit" Urban Planning}

In 1955, the federal competition for new industrial housing typologies took place. By this year, the construction of the first housing blocks on the outskirts of New Belgrade, in Tošin bunar, had already been finished. However, the uproar that the project caused was still present and being resolved: never again was a design like this to be built in Yugoslavia, especially not in New Belgrade. The design by Vrbanić and Ilić, architects of the transitional office, the "Institute for the study and concretisation of the problems of New Belgrade", was based on adapted concept of Soviet microrayons, that was just (re)emerging from scholarly literature. Above all, the typology was the same type of modest workers housing that was being built all over the country: a hiproof sitting on top of the five-story structure with perforated concrete elements on the facade. What was even worse, the applied type of construction and the layouts were something that the profession strived to eliminate. The 'reinforced brickwork' and small 'housemaid' rooms of this block were heavily criticised at the Counsel of Yugoslav architects in Dubrovnik in 1950, which was also considered to be the profession's final rupture from even the smallest traces of socialist realism in Yugoslav architecture, and a rupture from traditional construction.

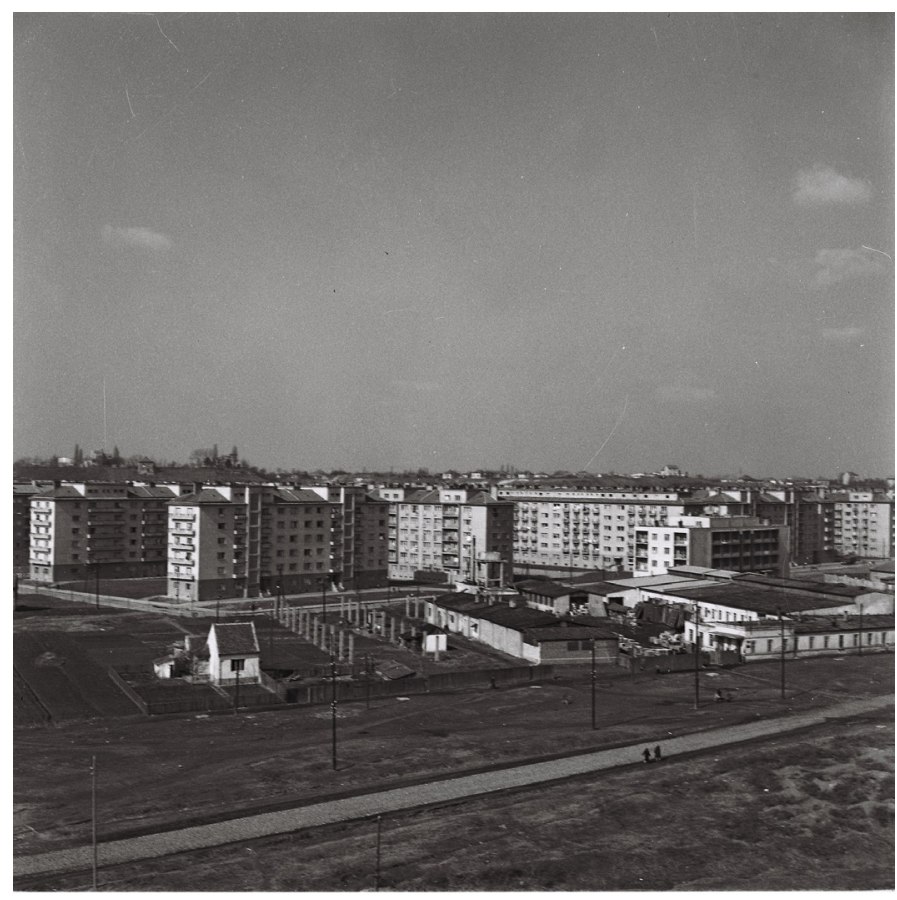

Fig. 2 The housing estate Tošin bunar (Block 7, New Belgrade), beginning of the 1960s. Source: Urban Planning Institute of Belgrade 
The rupture was easy to follow through in case of exterior design and design layout. When it came to technology and planning - bricks would never disappear from Yugoslav construction sites, alongside with the microrayon planning concept, which went hand in hand with industrialisation practices. It was simply the pragmatic thing to do: although set for the path of full industrialisation, soon it was clear that the circumstances were favourable for semi-prefabricated types of structures with considerable improvising and prototyping. New Belgrade proved to be a perfect polygon for such experimentation. The construction companies would start using (and later upgrading) certain technological solutions - which mainly consisted of applying open systems of prefabrication. Encouraged by the administrative, financial and logistical support of the state for the industrialisation programmes, many companies went in this direction: buying the equipment, forming research offices and laboratories, and most important - experimental construction sites. A competition would occasionally be announced, and afterwards, a construction site would be open for bidding.

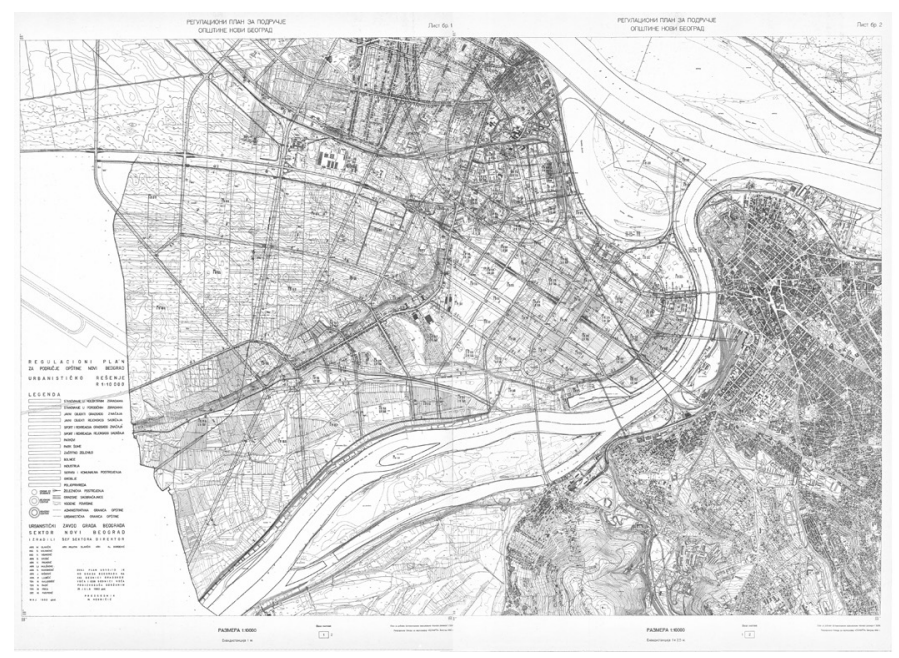

Fig. 3 Blank map of the Regulation Plan of the Area of New Belgrade Municipality, 1962. Source: Urban Planning Institute of Belgrade

As the planning authorities took it upon themselves to carry out a "review of Yugoslav architecture" (Stojanović, p. 224, GMGB 21), professional competitions were a convenient tool for planning. However, some framework had to be provided after a (lost?) decade and a half of research, experimenting and planning (without realisation). This aspect is not discussed in this paper, rather the realised plan: The Regulation Plan of the Area of New Belgrade Municipality from 1962 (leads: Milutin Glavički, Aleksandar Đorđević). The plan was produced following the design competition for the Central Zone of New Belgrade and Block 21, and would introduce the concept of the blank map, where just a gabarit or template of a block or building would be drawn, depending on the stage of detailed planning. Through later designing processes, this gabarit would be filled in with functions and details of the elevation. The word 'gabarit' came from French terminology, and the correct translation would be 'regulation' or 'template'. However, the foreign term stuck as a way of naming this specific practice in planning; later, it came to be used as a pejorative term to defame the planners and the city itself.

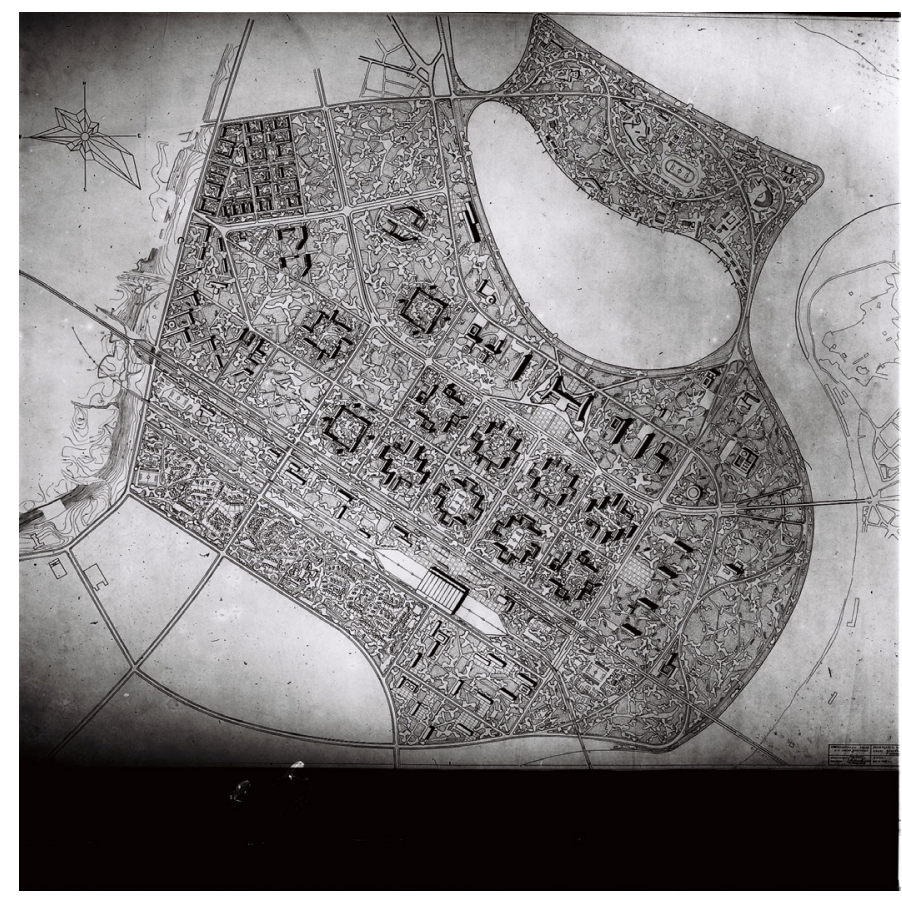

Fig. 4 The layout of Central Zone per the plan of Branko Petričić, part of the General (Master) Plan of Belgrade from 1950. Source: Urban Planning Institute Belgrade

The plan, from 1962, absorbed the previously built structures of Tošin bunar and Community (mesna zajednica) Fontana, blocks 1-5, built per the plan of Branko Petričić, as a segment of the General (Master) Plan of Belgrade from 1950. Petričić's plan was the important transitory solution between the mentioned hip-roofed units on the very edge of the New Belgrade's rayon, and the (high) modernist Central Zone, the peak of the city's design. The construction of Central Zone was constantly delayed, waiting for better conditions in terms of planning, design and technology. Petričić was working his way towards it by adapting the urban and architectural layouts to facilitate the application of prefabricated systems, through using the archetypal modernist structures: tower, slab and meander. The layouts were organised in such a way as to keep clear the central and peripheral area of the block, so the crane for the construction could easily move the prefabricated pieces of structure, stored in the centre of the block. Hence 'crane urbanism' - urbanism which revolves around prefabricated technology.

The practice would continue with planning and building the Central Zone, which was the major milestone in the planning of the city. The plan from 1962 was essentially one of the results of the competition for the Central Zone from 1960. It produced a layout for the Central Zone, a layout for Block 21 as a module 
and model urban unit of the zone, which elaborated the process of developing the zone via the experimentation in planning, designing and building. Its demise would eventually lead to the disastrous hijacking of these practices and the construction of the structures on the axis of the zone, in Blocks 24, 25 and 26 , that in many ways, did not correspond to the original plan.

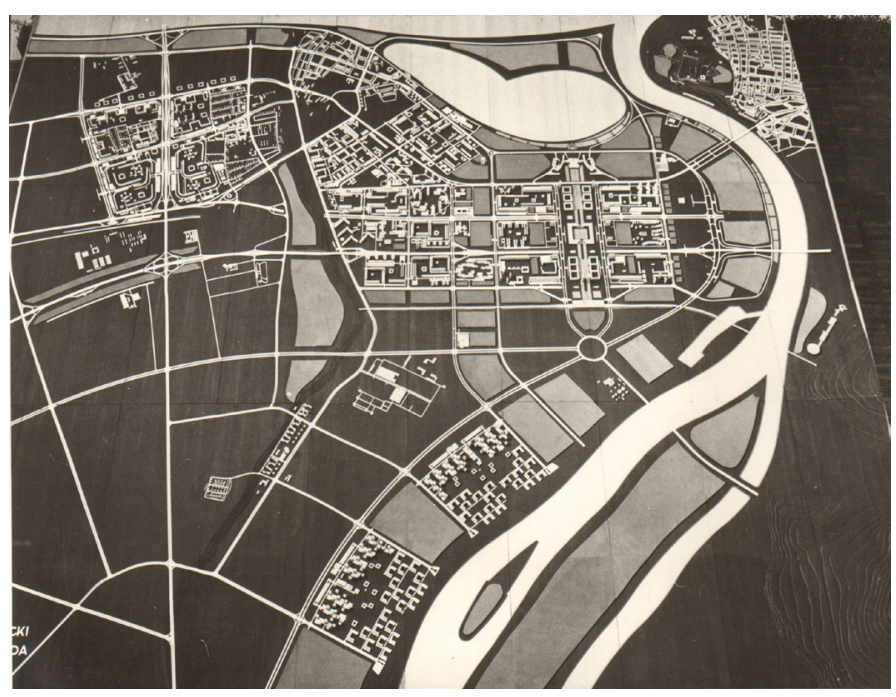

Fig. 5 Photo of the modular model of New Belgrade in the Urban Planning Institute: after each competition, a detailed plan is developed, block by block, and placed onto the large model of blank blocks according to the plan from 1962. Source: collection of Miloš Jurišić.

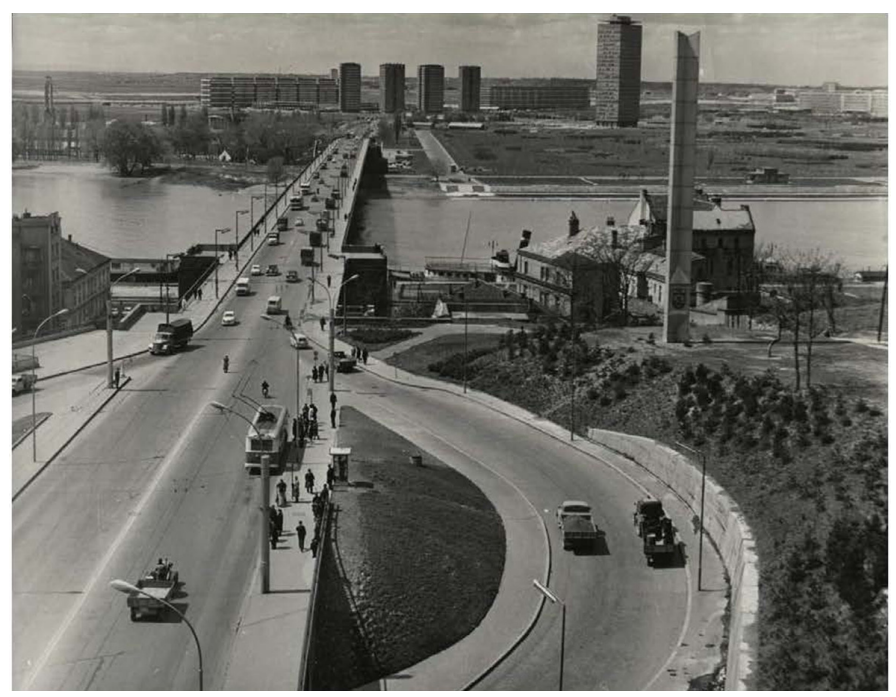

Fig. 6 The view of New Belgrade from Brankova Street: in focus, is Block 21 under construction (buildings S1-6 and B8 \& B9); to the right, the Federal Executive Council, and to the left, the Old Fairground. cca. 1965. Source: collection of Miloš Jurišić.

\section{The Implementation: From Dynamic Urban Laboratory to Socialist Corporatism}

The challenge of New Belgrade was multifaceted. Once the draining of the swamp was completed, there were other problems to resolve. Although it seemed an ideal site to design and plan on, construction on this terrain was quite a complex issue.
The foundations of the city were on sand of a low load-bearing capacity, which meant that pile foundations would be required; this option was more expensive and demanded adequate equipment, as well as additional time for the structures to set. The challenge was to keep the density of construction low, have as light structures as possible and prevent the flooding of the area. The perimeter blocks were built using the traditional technology, but the more the city approached its centre, the more sophisticated technology and design would get. Not many investors could take up this venture. Consequently, the Yugoslav People's Army was the major investor, alongside the Republic of Serbia's and Federation administration.

The contractors were the companies connected to the Army, mainly GP Napred, but also Ratko Mitrović, 7. juli and Hidrogradnja Čačak. These companies were pioneers in applying prefabrication and semi-prefabrication technology, based on the home-grown systems IMS Žeželj and Jugomont. As previously referred to, the emergence of these technologies was initiated by a state-organised competition, and implementation immediately followed - on many sites all over the country. New Belgrade was no exception, but the implementation of the prefabricated systems had some peculiarities. Only light prefabricated structures could be used, designed to reduce the weight of the building. The most famous among them was the prestressed IMS Žeželj system, designed by Branko Žeželj with New Belgrade in mind. The weight of the building was 30\% less than usual, could be built very quickly and use a variety of finishes since the structural load-bearing elements were separate from the facade and interior elements; it could be assembled by the previously non-qualified workforce after a minimum of training. Furthermore, the system was favoured by architects, due to its considerable flexibility: the competition calls would often state that the housing estates should be designed for prefabricated technology, so IMS was often the first choice.

The IMS Institute held the patent to the system, which was sold to different construction companies - alongside other systems such as Jugomont - who would then have to find a way to merchandise and sell their services. These companies would eventually go on to compete for public tenders for the construction of these estates and blocks. However, the state authorities would often intervene, via investors, for the companies to split the jobs and keep the orders coming to those less favoured - in order to stay solvent. Hence, from the very beginning, the process of industrialisation of the construction was undermined by the process of industrial pauperisation, which was also the major problem of the New Belgrade Central Zone. The combination was almost typical - a company using the new prefabricated system, paired with a company using modified traditional technology, overridden and somewhat forced into a semi-prefabrication production typology.

Block by block; it looks somewhat like the following: Block 21 was built by two companies. One was Komgrap - a 
fading state-owned giant, somewhat specialised for building the 'infills' in the city centre. This company built the highrises the classic way, by casting skeletal structure on site and filing it with prefabricated ceilings and building the regular walls. The other one was GP Neimar - the Army's construction company, which bought IMS Žeželj patents and started experimenting with the technology on this very site. Block 22 was also built by GP Neimar, just like Building 5 in Block 23 - the rest of which was built by GP Ratko Mitrović using the moving formwork technology. Block 28 was an experiment within the experiment, but nevertheless, the first fully industrialised site with a peculiar funding scheme. The block was built by the JINGRAP consortium of four developers, as a part of the effort of building for the market ${ }^{1}$ and with UN technical assistance for improving the features of the technology. Block 30 was also built by a consortium of five companies, combining semi prefabricated and prefabricated solutions. This block had two major changes to the architectural layout due to false assumptions about embassies and foreign representatives being potential buyers. However, this was not the case; consequently, the size of apartments had to be reduced to smaller units to sell more easily to local companies, causing a lot of havoc and problems with design and construction.

Block 29 was constructed by a single company, GP Rad, but it's development was funded and organized by the business consortium of various companies called INPROS, joined by the City's Housing Company. This block shows the signs of the corruption of the system that was already set in motion on other sites. Two typical examples included invited or internal competitions for employees of INPROS, which set in motion the non-transparent decisions about the societal property; the land concession was transferred to INPROS, which built and sold the lucrative part - the housing; the land for the rayon centre was kept unbuilt for 30 years, and then taken by one of the remaining members of the consortium to - build and sell the lucrative componenent, which was housing, but in the situation of changed socio-economic and legal circumstances. A similar situation applied in case of Block 24, but with the heavy influence of Energoprojekt whose architects, Bogdan and Vladimir Slavica won the competition for this block by creating a post-modernist coat of silicate brick and pitched roof for the "good old" IMS Žeželj structure. The circle was finally closed: thirty years later, New Belgrade was back at the beginning, masking its modern identity. On a larger scale, that was the end of the central axis of the Central Zone. As per the Po-Mo

1 Market is here referred to as a specific type of closed market that functioned only for the companies, buying the flats for their employees and then distributing within the company/organization by the priority lists. A private person could obtain an apartment in a different way: by joining/forming a cooperative, or building a private house - but only in very limited amount of locations in Belgrade. Hence, the explosion of illegal and informal construction. paradigm, the buildings were positioned randomly in the block, creating a visual and material barrier to continue any planning according to the plan from 1962; there were no central functions, but again, just housing.

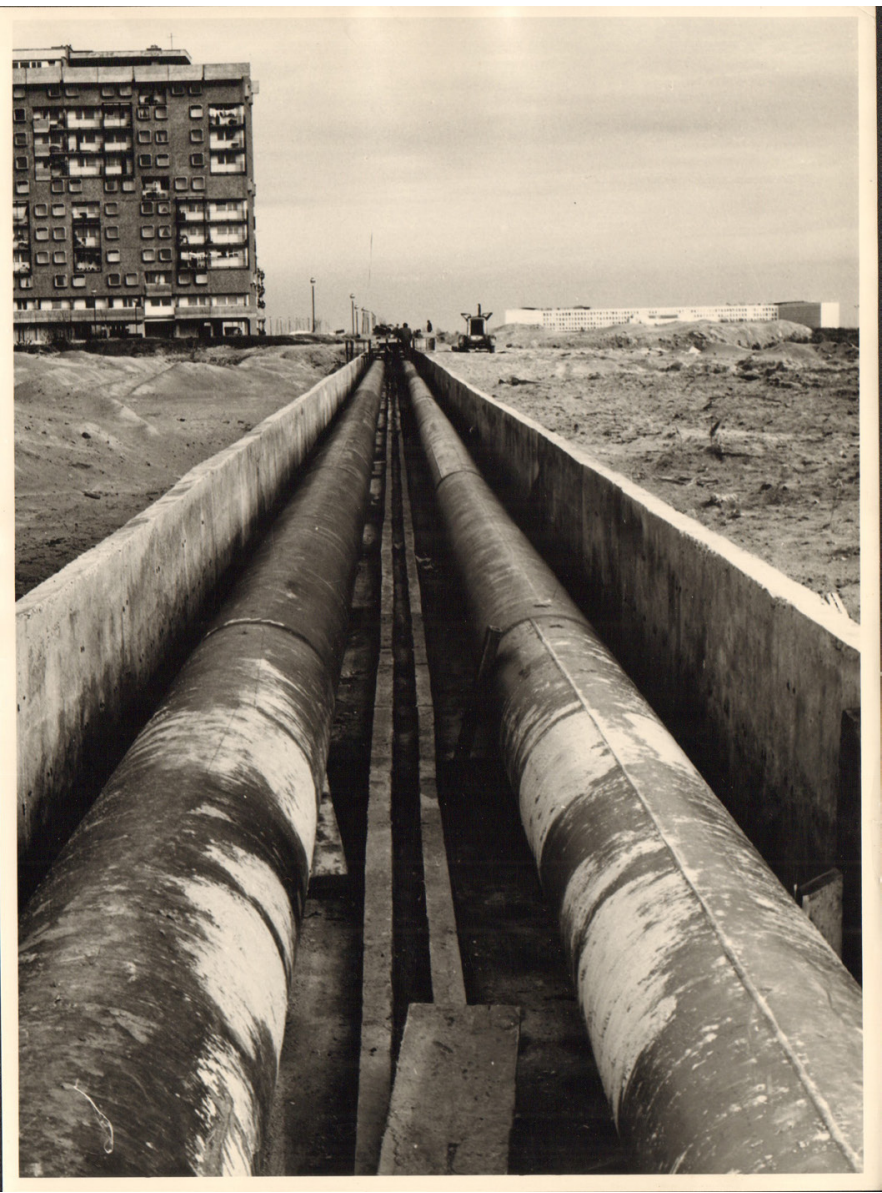

Fig. 7 Block 28 and the infrastructure being built. In the background, the building of the Federal Executive Council, cca. 1970. Source: Urban Planning Institute.

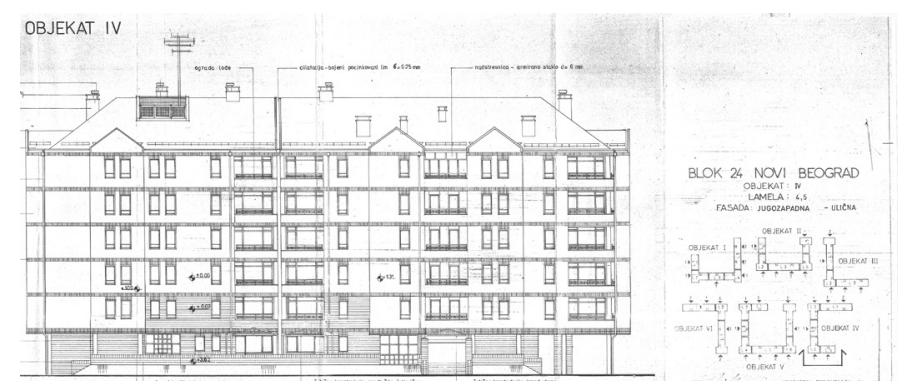

Fig. 8 Elevations and urban layout of Building 4 in Block 24, 1986. Source: Historical Archive of the City of Belgrade.

However, this was not the sole problem - the Energoprojekt was in crisis, having difficulties getting enough work abroad to maintain the company. So, the company shifted its focus inward, to the local market, for which it was oversized and not well adjusted. Being primarily oriented towards export, Energoprojekt ran its business as per local regulation - mostly based on international and British (colonial) law, since it operated 
mainly in former colonies. The company even earned its reputation in the country as being the socialist corporation, a somewhat privileged business that operated within some blurry framework of 'in-betweenness'. During the 1980s, when the country started collapsing, management of this (and many similar) company (companies) 'went rogue' and started exploiting the system, either in a desperate need not to go bankrupt or gradually preparing for the transition to capitalism. The language was already there: it is enough to just browse through the bulletins of this organisation and notice the discrepancy between the official language of the company and that of the legal system (still) in power. The moment was also convenient for this kind of action: while the project was developed - it was already the 1990s, a very difficult period for the city and the country, which soon dissolved into a bloody war. The blocks of New Belgrade were especially despised by everyone as the legacy of communism, so the laissez-faire gained a new, spatial interpretation. Consequently, based on the results of the internal competition for architectural design of Arena, Energoprojekt got the land. Instead, to the side of the Block 25, as per the new plan from 1986, the building was set centrally, undermining further the planning process and continuing to build a string of barriers on the axis of the Central Zone. Block 26 was and still is more of the same, but with a difference, that of having two companies, Napred and Energoprojekt, building and fighting over the land that today is, officially, their property, just like the buildings they built on it in the 2000s.
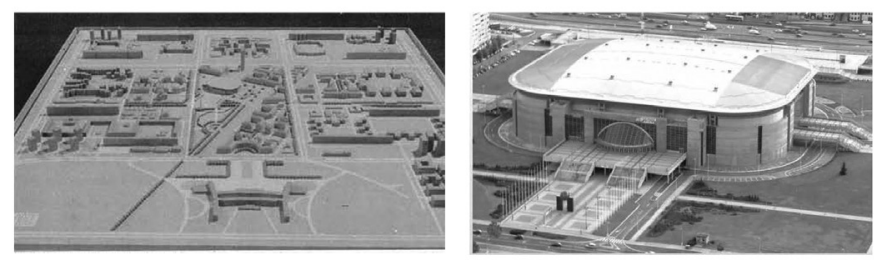

Fig. 9 Plan of the Central Zone from 1986 with the Arena's planned position (left) and Arena upon construction centrally located in Block 25, cca. 2006. Source: Bulletins of Energoprojekt from November 15th, 1991 and Jubilee Catalog from 2006.

\section{The Hybrid Approach to Planning? A Side Note on the Urban Planning Institute(s)}

The story of New Belgrade cannot be told without introducing the institution in charge of its planning. It should be noted that the New Belgrade construction came as a great surprise to the rest of the world, since it was the local institutes that were planning, designing and building the city. Foreign correspondents were obsessed with the project, constantly flocking to the offices of the heads of the Urban Planning Institute of the City of Belgrade. This surprise was entirely because there was no previous experience of such a scale. No city had been built from scratch in the country, at least not in recent history, so the profession had no previous experience. Very early on, after the end of the Second World War, it was decided that the Yugoslav administration would allocate resources to establish the professional networks of - among others - a hierarchical string of federal - republic - regional - city planning institutions. These institutions started developing their approaches to various urban designs, resolving the problems of the communities. If they were to learn from their own mistakes - let them learn! However, it WILL be design-and-build and in-the-house/ country project!

The important thing to point out, in this case, was the grooming of local expertise, which had two major aspects to its background.The personnel emerged from peculiar schools of architecture in Belgrade, Zagreb and Ljubljana, and there was continuous exposure to foreign influences and circulation of knowledge, mostly uninterrupted by the mainstream Cold War politics. The local schools of architecture and urban planning maintained different scholarly approaches over the years, given the fact that the first experts were educated abroad. The Belgrade school was particularly interesting. When the school of architecture, with predominantly polytechnic curriculum, was established at the end of $19^{\text {th }}$ century, expertise came mostly with scholars from the Austro-Hungarian empire, Germany and Switzerland. After the First World War, the situation changed: it was the UK, France and Czechoslovakia who accepted Yugoslav scholars. A significant boost to the profession came from Russia, as an unexpected effect of the October Revolution - White Russian refugees were immediately employed by the Kingdom's Ministry of Construction. Other parts of Yugoslavia also had various international connections, and all these thoughts and influences clashed together in the three schools of architecture of this new nation. However, it was only after the Second World War that the progressive ideas of modernists were achieved: an entire generation was frustrated by the corruption and the open obstruction by the inter-war municipal authorities ${ }^{2}$.

In post-war Belgrade, it was the Urban Planning Institute of the City of Belgrade that dealt with the development of the city, and within it, there was an independent department for New Belgrade. This institute was well integrated and very well connected within the network of Yugoslav institutes of urban planning, founded and organised basically on the re-adapted Soviet model of central planning offices, but with an avid level of autonomy. However, due to the previously mentioned plurality of the professional scene, the specificities of the reconstruction and production of the space, scale, and legal framework, quite early on, it was clear that a local approach must be developed.

Due to the specific nature of their work, the institutes were receiving literature and journals from all over the world,

2 Well described by a significant researcher of urbanism of Serbia, Branko Maksimović, who would write for newspapers about the speculation with the land \& administrative region of Belgrade and non-implementation of planning documents (later published in his book, p.45-48). 
completely blurring the boundaries of the Cold War. The library of the Institute still has Architektura Warszawa next to Japan Architect - or more accurately, a sequence of periodicals from the most important productions of the world. Furthermore, all of the prominent institutes had started their publishing activity, out of which the internal-use edition of the Translations (Prevodi) was the most interesting one. In these publications, one could find a set of texts, which were selected and translated based on the current needs of the planning institution that was publishing the texts. Hence, even though many of the plans were lost, it is possible to retrace the production based on the titles: Man, flat and neighbourhood (FR) or Practices and Experiences in the Policy of the Expropriation (BE) or The Construction of the Viennese Metro System (AT). The institutes' network would constantly make comparative studies of foreign cases and legal documents, and put together publications of translations, analysis and finally - synthesis, as a follow-up, and distribute them to the network Yugoslav institutes to use.

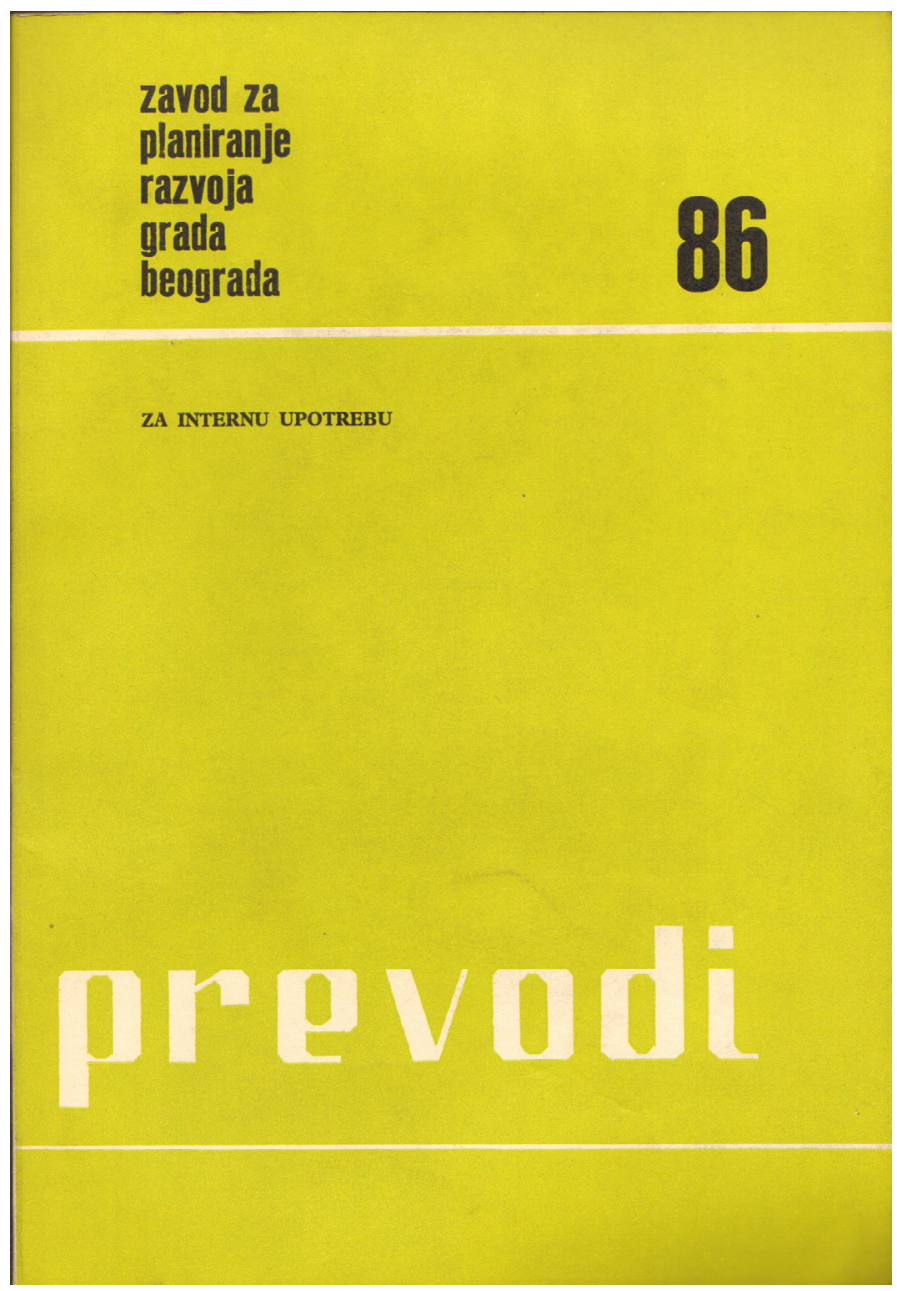

Fig. 10 Cover of the translations (Prevodi). Source: Source: Urban Planning Institute.

\section{Conclusion: Mass Housing as (Mass) Heritage?}

The current condition of the ensemble in New Belgrade is not particularly good. The years of use, neglect and disrepair of the architecture and constant pressure on the urban fabric, increasingly being further developed and reshaped, are changing the appearance of this area of the city. Saturation point is approaching: New Belgrade was the best possible gift to any of the post-Yugoslav governments in Serbia and Belgrade, providing a lot of infrastructurally equipped greenfield zones, which are now almost all built or in the process. The green areas are under threat as they are being targeted as building land, while the existing structures are looked upon as a prey for developers: as potential sites for energy sanitation and extension/expansion projects, with the addition of floors or balconies. On the other side, the heritage protection services are reluctant to deal with this heritage, because, under current circumstances, it is an overwhelming amount of work that surpasses their capacities. Hence, mass housing is gradually becoming a massive problem, that would need an appropriate, mass solution. The author would argue that we need to go back and consider the experiences of its emergence: as a product of many organised, small-series, customised productions, well planned and professionally debated on so many levels.

\section{References}

Blagojević, L. (2007). Нови Београд: оспорени модернизам [New Belgrade: disputed modernism]. Belgrade: Institute for textbooks and teaching aids, Faculty of Architecture University of Belgrade, Belgrade Institute of Heritage Protection. (in Serbian)

Jovanović, J. (2014-2016). Анализа претходно заштићене целине Централна зона Новог Београда, Блокови 21, 22, 23, 24, 25, 26, 28, 29, 30. Урбанистичко - архитектонска анализа. [Analysis of the Central zone of New Belgrade under tentative protection, Blocks 21, 22, 23, $24,25,26,28,29,30$. Urban planning and architecture analysis]. Unpublished research material of Belgrade Institute of Heritage Protection. (in Serbian)

Maksimović, B. (1983). Ideje i stvarnost urbanizma Beograda 1830-1941. (Ideas and Reality of Belgrade Urbanism 1830-1941.), Zavod za zaštitu spomenika kulture Grada Beograda, Beograd. (in Serbian)

Mrduljaš, M., Kulić, V. (eds.) (2012). Unfinished Modernisations Between Utopia and Pragmatism. Association of Croatian Architects, Zagreb.

Technical documentation: Blok 21, 22, 23, 24, 25, 26, 28, 29, 30. Historical Archives of Belgrade - Novi Beograd SO. (in Serbian)

Vujnović, R. (1997). Dinamika izgradnje grada - Jedna etapa u izgradnji $i$ rekonstrukciji Beograda. (Dynamics of the city construction - one stage in construction and reconstruction of Belgrade.), Izgradnja magazine, Association of engineers and technicians of Serbia and Association of architects of Serbia, Belgrade. (in Serbian) 